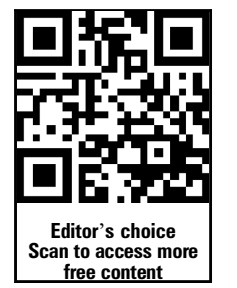

- Additional material is published online only. To view please visit the journal online (http://dx.doi.org/10.1136/ jmedgenet-2013-101803)

${ }^{1}$ Centre for Molecular, Environmental, Genetic and Analytic Epidemiology, The University of Melbourne, Parkville, Victoria, Australia ${ }^{2}$ Cancer Epidemiology Centre, Cancer Council Victoria, Carlton, Victoria, Australia

\section{Correspondence to} Dr Aung Ko Win, Centre for Molecular, Environmental, Genetic and Analytic Epidemiology, Melbourne School of Population and Global Health, Level 3, 207 Bouverie Street, The University of Melbourne, Parkville, VIC 3010, Australia; awin@unimelb.edu.au

Received 8 May 2013 Revised 2 July 2013 Accepted 17 July 2013 Published Online First 16 August 2013

\footnotetext{
To cite: Win AK, Maclnnis RJ, Dowty JG, et al. J Med Genet 2013;50:785-793
}

\title{
Criteria and prediction models for mismatch repair gene mutations: a review
}

\author{
Aung Ko Win, ${ }^{1}$ Robert J Maclnnis, ${ }^{1}{ }^{2}$ James G Dowty, ${ }^{1}$ Mark A Jenkins ${ }^{1}$
}

\section{ABSTRACT}

One of the strongest predictors of colorectal cancer risk is carrying a germline mutation in a DNA mismatch repair (MMR) gene. Once identified, mutation carriers can be recommended for intensive screening that will substantially reduce their high colorectal cancer risk. Conversely, the relatives of carriers identified as noncarriers can be relieved of the burden of intensive screening. Criteria and prediction models that identify likely mutation carriers are needed for cost-effective, targeted, germline testing for MMR gene mutation. We reviewed 12 criteria/guidelines and 8 prediction models (Leiden, Amsterdam-plus, Amsterdam-alternative, MMRpro, PREMM 1,2,6, MMRpredict, Associazione Italiana per lo studio della Familiarità ed Ereditarietà dei tumori Gastrointestinali (AIFEG) and the Myriad Genetics Prevalence table) for identifying mutation carriers. While criteria are only used to identify individuals with colorectal cancer (yes/no for screening followed by germline testing), all prediction models except MMRpredict and Myriad tables can predict the probability of carrying mutations for individuals with or without colorectal cancer. We conducted a meta-analysis of the discrimination performance of 17 studies that validated the prediction models. The pooled estimate for the area under curve was $0.80(95 \% \mathrm{Cl} 0.72$ to 0.88$)$ for MMRpro, 0.81 (95\% Cl 0.73 to 0.88$)$ for MMRpredict, $0.84(95 \% \mathrm{Cl} 0.81$ to 0.88$)$ for PREMM, and $0.85(95 \% \mathrm{Cl} 0.78$ to 0.91$)$ for Leiden model. Given the high degree of overlap in the Cls, we cannot state that one model has a higher discrimination than any of the others. Overall, the existing statistical models have been shown to be sensitive and specific (at a 5\% cut-off) in predicting MMR gene mutation carriers. Future models may need to: provide prediction of PMS2 mutations, take into account a wider range of Lynch syndrome-associated cancers when assessing family history, and be applicable to all people irrespective of any cancer diagnosis.

\section{INTRODUCTION}

Lynch syndrome (OMIM 120435), previously termed Hereditary Non-Polyposis Colorectal Cancer (HNPCC), ${ }^{1}$ is an autosomal dominantly inherited disorder of cancer susceptibility caused by germline mutations in one of the DNA mismatch repair (MMR) genes: $\mathrm{MLH1}$ (chromosome 3p21.3), ${ }^{2}{ }^{3}$ MSH2 (chromosome 2p22-21), ${ }^{4}$ MSH6 (chromosome 2p16), ${ }^{5}$ and PMS2 (chromosome $\left.7 \mathrm{p} 22.2\right)^{78}$; or constitutional $3^{\prime}$ end deletions of EPCAM (chromosome 2p21). ${ }^{9} 10$ These mutations cause $2-5 \%$ of all colorectal cancers ${ }^{11-16}$ and $10-15 \%$ of colorectal cancers diagnosed before age 50 years. ${ }^{11} 1217$ They account for approximately 50\% of the excess colorectal cancer cases observed in first- degree relatives of a colorectal cancer case. ${ }^{18}$ Reported estimates of carrier frequency of germline mutations of these genes in the population vary depending on differences in assumptions; from approximately 1 in 300 to 1 in $3000 .^{15} 16 \quad 19-22$ Mutation carriers are at substantially increased risk of cancers of the colon, rectum, endometrium, stomach, ovary, ureter, renal pelvis, brain, small bowel and hepatobiliary tract, and the diagnoses of these cancers occur at younger ages than for the general population on average. ${ }^{23}$ Additionally, mutation carriers may also be at increased risk of cancer of the pancreas, ${ }^{2425}$ prostate, $^{26}$ breast $^{25}{ }^{27-29}$ and cervix. ${ }^{30}$

Screening colonoscopy, ${ }^{31} 32$ prophylactic hysterectomy and bilateral salpingo-oophorectomy ${ }^{33}$ decrease the risk of colorectal, endometrial and ovarian cancer respectively for MMR gene mutation carriers. As a chemoprevention, $600 \mathrm{mg}$ aspirin per day for an average two years has been shown to approximately halve the risk of colorectal cancer for MMR gene mutation carriers. ${ }^{34}$ Given the substantial risk of cancers and the availability of effective interventions to reduce risk, identifying mutation carriers can prevent or minimise the impact of a substantial number of cancers. Once carriers are identified, testing of their relatives can also be performed, and this will identify additional carriers who can also benefit from screening, and non-carriers who can be spared the intensive screening and prophylactic surgery recommended for their mutation-carrying relatives.

As germline testing is required to confirm mutation carrier status, untargeted testing is not costeffective given the cost of germline sequencing and the rarity of carriers. Attempts have been made to develop criteria to categorise people by their probability of carrying a mutation, and prediction models have been developed to estimate a person's probability of carrying a mutation. These criteria and models can be used to triage for germline sequencing. The aim of this review was to catalogue and describe the published criteria and prediction models, and to compare the performance of the prediction models for MMR gene mutation status.

\section{CRITERIA AND GUIDELINES}

Several criteria and guidelines have been developed for categorising families or individuals into those most likely to be carrying a MMR gene mutation so they can be triaged for germline testing. Given Lynch syndrome-associated colorectal cancers typically exhibit high level of DNA microsatellite instability (MSI) and/or loss of MMR protein expression that can be detected by immunohistochemistry (IHC), these techniques have been widely used as a screen for likely mutation carriers. 
Here, we categorise these criteria as 'clinical criteria' if they are only based on personal and family history of cancer, including ages and sites of diagnoses, and as 'clinicopathological criteria' if they are based on tumour pathology as well as the clinical features described above.

\section{CLINICAL CRITERIA}

\section{Amsterdam criteria}

Amsterdam Criteria-I developed by the International Collaborative Group on HNPCC (ICG-HNPCC) in $1990^{35}$ is based only on family history of colorectal cancer (box 1). The strengths of the Amsterdam Criteria-I criteria are: that they are relatively simple to describe and use; and they are widely recognised internationally. The limitations of the Amsterdam Criteria-I are: (1) they do not take into account extracolonic cancers that are recognised as Lynch syndrome spectrum tumours; (2) they have reduced sensitivity for small families ${ }^{36}$ and (3) they require accurate recall and reporting of family history. Estimates of the Amsterdam Criteria-I sensitivity range between $47 \%$ and $91 \%$, and specificity between $62 \%$ and $84 \% .^{37-42}$ MMR gene mutations are observed in approximately $50 \%$ (positive predictive value) of families that met the Amsterdam Criteria-I. ${ }^{37} 3943$

In 1998, the ICG-HNPCC devised the Amsterdam Criteria-I to produce the Amsterdam Criteria-II which broadened the definition of family history by including specified extracolonic

\title{
Box 1 Clinical criteria to identify mismatch repair gene mutations
}

\author{
Amsterdam Criteria-I (1990) $)^{35}$ \\ - At least three relatives affected with CRC; one of them should be a first-degree relative to the other two \\ - At least two successive generations affected \\ - At least one affected relative with CRC before age 50 years \\ - Familial adenomatous polyposis should be excluded \\ - Tumours should be verified by pathological examination. \\ Amsterdam Criteria-II (1998) ${ }^{44}$
}

- At least three relatives affected with an HNPCC-associated cancer (large bowel, endometrium, small bowel, ureter, or renal pelvis); one of them should be a first-degree relative of the other two

- At least two successive generations affected

- At least one relative affected with CRC before age 50 years

- Familial adenomatous polyposis should be excluded in the CRC case(s) if any

- Tumours should be verified by pathological examination.

Modified Amsterdam Criteria (1993) 4748

- 'Very small families', which cannot be further expanded, can be considered as HNPCC even if there are only two CRCs in first-degree relatives; CRC must be present in at least two generations, and one or more CRC cases must be diagnosed under age 55 years

- In families with two first-degree relatives affected by CRC, the presence of a third relative with an early onset (before age 55 years) 'unusual' neoplasm or endometrial cancer is sufficient.

- Neoplasms are considered as 'verified' when histological reports, clinical charts, or death certificates are available.

Mount Sinai Hospital Criteria (MC) (1995) ${ }^{49}$

- Three individuals in at least two successive generations with at least one CRC, and two others with either gastrointestinal, genitourinary or gynaecological cancers with no age limit for the cancer diagnosis (MC-1)

- Any CRC patient diagnosed at $<35$ years of age irrespective of family history of cancer (MC-2)

- Any individual with multiple primary cancers of the sites associated with HNPCC irrespective of family history of cancer (MC-3). Familial adenomatous polyposis should be excluded.

Japanese Criteria (1991) ${ }^{50}$

- CRC patient with two or more first-degree relatives with CRC

- CRC patient with one first-degree relative with CRC and any of the following:

1. Age at onset of CRC(s) of less than 50 years.

2. Right colon involvement.

3. Synchronous and/or metachronous multiple CRCs.

4. Associated extracolorectal malignancy.

Familial adenomatous polyposis should be excluded.

Korean Criteria (1991)

- Vertical transmission of CRC or at least two siblings in a family, affected with CRC

- Development of multiple colorectal tumours or at least one CRC case diagnosed before age 50 years.

Chinese Criteria (2003) ${ }^{52}$

- At least two pathologically verified CRCs in a family; at least two of them first-degree relatives

- At least one of the following conditions has to be satisfied:

1. At least one case with multiple colorectal cancers or adenomas

2. At least one colorectal cancer diagnosed before age 50 years

3. At least one case with an extracolonic cancer (gastric, endometrial, small bowel, ureter and renal pelvis, ovarian or hepatobiliary malignancies).

HNPCC, Hereditary Non-Polyposis Colorectal Cancer. 
cancers. ${ }^{44}$ Consequently, sensitivity increased (range between $77 \%$ and $81 \%$ ) though specificity decreased (between $46 \%$ and $68 \%) .^{384245} 46$

\section{Other clinical criteria}

Other clinical criteria have been developed, including: modified Amsterdam Criteria, ${ }^{47} 48$ the Mount Sinai Hospital Criteria, ${ }^{49}$ Japanese Criteria, ${ }^{50}$ Korean Criteria ${ }^{51}$ and Chinese Criteria ${ }^{52}$ (see detail in box 1). Note that all these clinical criteria are only used to identify Lynch syndrome families rather than individuals.

\section{CLINICOPATHOLOGICAL CRITERIA \\ Bethesda guidelines}

The Bethesda guidelines were developed in $1997^{53}$ and revised in $2004^{23}$ (box 2). MSI testing was recommended for any colorectal cancer case meeting at least one of the following criteria: Amsterdam-like family history of a range of cancers; particular pathological features of the tumour; and early age at diagnosis. Widening the inclusion criteria by adding indicators, resulted in increased sensitivity compared with the clinical criteria described above $(89 \%, 95 \%$ CI $86 \%$ to $92 \%)$, and reduced specificity $(53 \%, 95 \%$ CI $49 \%$ to $58 \%){ }^{42}$
Age of diagnosis-only criteria

The Melbourne Criteria ${ }^{54}{ }^{55}$ recommends that all colorectal cancer cases diagnosed before age 45 years should be tested for MMR-deficiency using IHC regardless of family history, and achieves a sensitivity of $100 \%$ (95\% CI $82 \%$ to $100 \%)$ and a specificity of $91 \% \quad(95 \%$ CI $83 \%$ to $96 \%)$. The Perth Criteria $^{56}{ }^{57}$ recommends to test MMR-deficiency using IHC and/or MSI for all colorectal cancer cases diagnosed before age 60 years regardless of family history, while the Jerusalem workshop $^{22}$ recommends to test for cases before age 70 years.

\section{Universal screening}

Several groups recommend that all cases of colorectal cancer should be tested for MMR-deficiency regardless of their age at diagnosis or family history ${ }^{13} 14$ S8-61 $^{2}$ given that a proportion of colorectal cancers caused by MMR mutations do occur at old age. This so-called 'universal screening' has virtually complete sensitivity (100\%; $95 \%$ CI $99.3 \%$ to $100 \%$ ) as everyone with colorectal cancer is tested for MMR-deficiency by MSI and/or IHC. $^{60}$ To minimise loss of specificity due to substantial MLH1 methylation-causing MMR-deficiency in the elderly, the proponents of universal testing recommend testing all MLH1 and/or PMS2-deficient tumours for MLH1 methylation (as well as the V600E mutation in the BRAF oncogene) ${ }^{62}{ }^{63}$ prior to germline testing. Some claimed that universal screening is less

\section{Box 2 Clinicopathological criteria to identify mismatch repair gene mutations}

Bethesda Guidelines (1997) ${ }^{53}$

Colorectal tumours should be tested for MSI in any of the following situations:

- Individuals with cancer in families that meet the Amsterdam Criteria

- Individuals with two HNPCC-related cancers, including synchronous and metachronous colorectal cancers or associated extracolonic cancers*

- Individuals with colorectal cancer, and a first-degree relative with colorectal cancer and/or HNPCC-related extracolonic cancer and/ or a colorectal adenoma; one of the cancers diagnosed at age $<45$ years, and the adenoma diagnosed at age $<40$ years

- Individuals with colorectal cancer or endometrial cancer diagnosed at age $<45$ years

- Individuals with right-sided CRC with an undifferentiated pattern (solid/cribriform) on histopathology diagnosed at age $<45$ years

- Individuals with CRC which was composed of $>50 \%$ signet ring cells and diagnosed at age $<45$ years

- Individuals with adenomas diagnosed at age $<40$ years.

Revised Bethesda Guidelines (2004) $)^{23}$

Colorectal tumours should be tested for MSI in any of the following situations:

- CRC diagnosed at age $<50$ years

- Presence of synchronous or metachronous HNPCC-related tumours, $\uparrow$ regardless of age

- CRC with MSI-high histology $\neq$ diagnosed in individuals aged $<60$ years

- CRC diagnosed in one or more first-degree relatives with an HNPCC-related tumour, with one of the cancers being diagnosed at age $<50$ years

- CRC diagnosed in two or more first-degree or second-degree relatives with HNPCC-related tumourst, regardless of age

Melbourne Criteria (2005) $)^{54}$

- Individuals with CRC diagnosed at age $<45$ years irrespective of family history should be tested for mismatch repair deficiency using IHC.

Perth Criteria (2012) $)^{57}$

- Individuals with CRC diagnosed at age $<60$ years irrespective of family history should be tested for MSI.

Jerusalem Recommendation (2010) $)^{22}$

- Individuals with CRC diagnosed at age $<70$ years irrespective of family history should be tested for MSI or mismatch repair deficiency using IHC.

*Endometrial, ovarian, gastric, hepatobiliary, small bowel, ureter and renal pelvis tumours.

tcolorectal, endometrial, stomach, small bowel, ovarian, pancreas, ureter and renal pelvis, biliary tract, and brain tumours, sebaceous gland adenomas and keratoacanthomas.

¥Presence of tumour-infiltrating lymphocytes, Crohn's-like lymphocytic reaction, mucinous/signet-ring differentiation, or medullary growth pattern.

HNPCC, Hereditary non-polyposis colorectal cancer; CRC, colorectal cancer; MSI, microsatellite instability; IHC, immunohistochemistry. 
cost-effective compared with having an age of diagnosis cut-off before 50 years ${ }^{55}$ or before 70 years, ${ }^{64}$ while one study claimed that universal screening is more cost-effective than age-targeted testing. ${ }^{65}$

None of these clinical and clinicopathological criteria provide the probability of being a MMR gene mutation carrier. They only indicate whether a colorectal cancer case should have their tumour tested for MSI and/or IHC testing, and depending on this result, to undergo germline testing for MMR gene mutations. ${ }^{66}$ These MSI and IHC tests require a pathologist, at least to select sections for staining. MSI testing needs to be conducted in a molecular laboratory, is more expensive, and does not provide information on which MMR gene is mutated, if any. Also, mutations cannot be identified for about one-third of those with a MMR-deficient colorectal cancer (even after screening for MLH1 methylation) tumour testing. ${ }^{14} 54$ The alternative of moving directly to germline testing, irrespective of tumour test results, would be too expensive and inefficient given only $2-5 \%$ of colorectal cancers are caused by germline MMR gene mutations. ${ }^{67}$ Further, studies have also shown that only a fraction of individuals who should be referred for molecular evaluation are actually referred. ${ }^{68}$

\section{PREDICTION MODELS \\ Why are prediction models required for risk prediction of MMR gene mutations?}

In addition to the limitations of all clinical and clinicopathological criteria that have been described above, they are not pertinent for: (1) individuals without colorectal cancer (except Amsterdam Criteria) and (2) individuals who have no relatives with colorectal cancer, who are able or willing to have their colorectal tumour tested for MMR-deficiency. For these individuals, statistical prediction models are needed to predict who are the most likely to be carriers based on their age and family history of colorectal and other Lynch syndrome spectrum cancers. Ideally, prediction models can quantitatively combine the complicated effects of many risk factors in a rational way; be easily updated when more accurate incidence data and population carrier frequencies become available; and are more widely applicable than clinical or clinicopathological criteria. For these reasons, risk prediction models for MMR gene mutations have been developed and used by physicians for their patients to help them decide whether to pursue germline testing or not.

\section{Existing risk prediction models for MMR gene mutations}

The currently available risk prediction models for MMR gene mutations are as summarised in table 1 : Leiden by Wijen et al, ${ }^{69}$ Amsterdam-plus by Lipton et al, ${ }^{70}$ Amsterdam-alternative by Lipton et al, ${ }^{70}$ MMRpro (previously known as CRCAPRO) by Chen et $a l,{ }^{71}$ PREMM $_{1,2}$ by Balmana $e t a l^{72}$ and PREMM $1,2,6$ by Kastrinos et al, ${ }^{73}$ MMRpredict by Barnetson et al, ${ }^{74}$ AIFEG (Associazione Italiana per lo studio della Familiarità ed Ereditarietà dei tumori Gastrointestinali) by Marroni et al, ${ }^{75}$ and the Myriad Genetics Prevalence table. ${ }^{76}$

All these models except MMRpredict ${ }^{74}$ and Myriad tables ${ }^{76}$ can predict the probability of carrying mutations for individuals or families with or without colorectal cancer. Leiden, ${ }^{69}$ Amsterdam-plus ${ }^{70}$ and Amsterdam-alternative ${ }^{70}$ models predict only at the family level while the other models predict at individual level. MMRpro ${ }^{71}$ and PREMM $_{1,2,6}{ }^{73}$ predict the probability of a mutation for each of the genes MLH1, MSH2 and MSH6, whereas the other models can only predict mutations in any MMR gene. None of the existing models take into account PMS2 mutations, which account for $15 \%$ of all MMR gene mutations $^{77}$ and have different cancer risk profile than other MMR gene mutations. ${ }^{78}$ Apart from MMRpro, ${ }^{71}$ PREMM $_{1,2}{ }^{72}$ and PREMM PR $_{1,2,6},{ }^{73}$ the models only take into account history of colorectal cancer and endometrial cancer, but not other Lynch syndrome-associated cancers. All models used multivariable logistic regression methods for their model development except AIFEG, ${ }^{75}$ MMRpro $^{71}$ and Myriad tables. ${ }^{76}$ AIFEG $^{75}$ and MMRpro $^{71}$ models require cancer data for full family pedigrees, and they applied Mendel's genetic laws to predict mutations within family. On the other hand, Myriad tables ${ }^{76}$ just uses the prevalence of mutation among all tested colorectal cancer cases. Most of the models are easy to use as they all are web-based or based on a statistical formula (table 1).

\section{Evaluation of existing prediction models for MMR gene mutations}

Before a risk prediction model can be recommended as a useful tool for individualised decision making in a clinical setting, it needs to be validated using an independent sample than that used to develop the model. ${ }^{79}$ The following characteristics were mainly evaluated by previous studies:

1. Discrimination (or precision): The concordance statistic (c-statistic) that corresponds to the area under a receiver operating characteristic curve (AUC) which plots sensitivity against one minus specificity. ${ }^{80} \mathrm{~A}$ c-statistic of 0.5 indicates that there is no discrimination between individuals who have mutations and those who do not, whereas 1.0 indicates perfect discrimination;

2. Calibration (or reliability): The ratio of the expected number of events (E) with the observed number of events (O) ${ }^{80}$ The ratio 1.0 indicates perfect calibration;

3. Accuracy: Sensitivity, specificity, positive and negative predictive values of a model for a given probability threshold.

We reviewed all previously published studies that evaluated the performance of MMR gene prediction models. Most of the studies evaluated discrimination (using AUC) and a few studies also evaluated calibration and accuracy. We conducted meta-analyses of the AUCs for the PREMM, ${ }^{72}{ }^{73}$ MMRpro, ${ }^{71}$ MMRpredict $^{74}$ and Leiden ${ }^{69}$ models to summarise their discrimination performance; and these meta-analyses were stratified by population-based or clinic-based samples that were used for validation. As a sensitivity analysis, we conducted the meta-analyses on just the studies that reported results for the three models (PREMM, MMRpro, MMRpredict) within the same study. Both random and fixed effects were fitted, and heterogeneity was tested using $I$-squared. All statistical analyses were performed using Stata V.11.0. ${ }^{81}$

We observed a total of 17 studies that evaluated the performance of prediction models for MMR gene mutations (see online supplementary table S1). Of them, four used population-based samples, ${ }^{74} 82-8410$ used clinic-based samples, ${ }^{71} 727^{75-91}$ and three used both clinic-based and population-based samples. $^{739293}$ Given there was significant evidence of heterogeneity between studies, we reported the pooled AUC values from random effect models (detail in table 2). The pooled AUC values from the combined analyses of population-based and clinic-based validation studies were 0.80 (95\% CI 0.72 to 0.88 ) for MMRpro, 0.81 (95\% CI 0.73 to 0.88 ) for MMRpredict, 0.84 (95\% CI 0.81 to 0.88 ) for PREMM, and 0.85 (95\% CI 0.78 to 0.91 ) for Leiden model (see online supplementary figures S1-4). When we restricted only to the seven studies (five clinic-based, one population-based and one both) validating three models within the same study, the AUCs were 0.81 (95\% CI 0.72 to 0.89 ) for MMRpro, 0.78 (95\% CI 0.68 to 0.89 ) for 
Table 1 Summary of existing risk prediction models for mismatch repair (MMR) gene mutations

\begin{tabular}{|c|c|c|c|c|c|c|c|c|c|}
\hline & Leiden $^{69}$ & Amsterdam-plus $^{70}$ & Amsterdam-alternative $^{70}$ & AIFEG $^{75}$ & MMRpro $^{71}$ & MMRpredict $^{74}$ & PREMM $_{1,2}{ }^{72}$ & PREMM $_{1,2,6}{ }^{73}$ & Myriad $^{76}$ \\
\hline Year published & 1998 & 2004 & 2004 & 2006 & 2006 & 2006 & 2006 & 2011 & - \\
\hline $\begin{array}{l}\text { CRC affected/ } \\
\text { unaffected }\end{array}$ & $\begin{array}{l}\text { Both affected } \\
\text { and unaffected }\end{array}$ & $\begin{array}{l}\text { Both affected and } \\
\text { unaffected }\end{array}$ & Both affected and unaffected & $\begin{array}{l}\text { Both affected and } \\
\text { unaffected }\end{array}$ & $\begin{array}{l}\text { Both affected and } \\
\text { unaffected }\end{array}$ & Affected only & Both affected and unaffected & $\begin{array}{l}\text { Both affected and } \\
\text { unaffected }\end{array}$ & $\begin{array}{l}\text { Affected } \\
\text { only }\end{array}$ \\
\hline Genes & MLH1, MSH2 & MLH1, MSH2, MSH6 & MLH1, MSH2, MSH6 & MLH1, MSH2 & MLH1, MSH2, MSH6 & $\begin{array}{l}\text { MLH1, MSH2, } \\
\text { MSH6 }\end{array}$ & MLH1, MSH2 & MLH1, MSH2, MSH6 & $\begin{array}{l}\text { MLH1, } \\
\text { MSH2 }\end{array}$ \\
\hline $\begin{array}{l}\text { Development } \\
\text { dataset }\end{array}$ & $\begin{array}{l}184 \text { CRC cases } \\
\text { from } 184 \\
\text { families; } \\
47(26 \%) \\
\text { mutation } \\
\text { carriers ( } 28 \\
\text { MLH1, } 19 \\
\text { MSH2) }\end{array}$ & $\begin{array}{l}250 \text { families recruited } \\
\text { from family cancer } \\
\text { clinics; } 34(14 \%) \\
\text { mutation carriers ( } 25 \\
\text { MLH1, } 8 \text { MSH2, } 1 \\
\text { MSH6) }\end{array}$ & $\begin{array}{l}250 \text { families recruited from } \\
\text { family cancer clinics; } 34(14 \%) \\
\text { mutation carriers }(25 \mathrm{MLH1}, 8 \\
\text { MSH2, } 1 \text { MSH6) }\end{array}$ & $\begin{array}{l}\text { Literature review: } \\
\text { published } \\
\text { estimates of } \\
\text { mutation } \\
\text { frequencies and } \\
\text { cancer penetrances } \\
\text { in carriers and } \\
\text { non-carriers }\end{array}$ & $\begin{array}{l}\text { Literature review: } \\
\text { meta-analyses of } \\
\text { mutation frequencies } \\
\text { and cancer } \\
\text { penetrances and } \\
\text { predictive value of } \\
\text { MSI test }\end{array}$ & $\begin{array}{l}870 \text { CRC cases } \\
\text { diagnosed age } \\
<55 \text { years, } \\
\text { recruited regardless } \\
\text { of family history; } \\
38 \text { ( } 4 \% \text { ) mutation } \\
\text { carriers (15 MLH1, } \\
16 \text { MSH2, } 7 \text { MSH6) }\end{array}$ & $\begin{array}{l}898 \text { individuals ( } 536 \text { affected with } \\
\text { CRC) with a personal or family } \\
\text { history of Lynch syndrome; } \\
130 \text { (15\%) mutation carriers ( } 58 \\
\text { MLH1, } 72 \text { MSH2) }\end{array}$ & $\begin{array}{l}4539 \text { individuals ( } 2526 \\
\text { affected with CRC) with a } \\
\text { personal or family history } \\
\text { of Lynch syndrome; } \\
525(12 \%) \text { mutation } \\
\text { carriers (204 MLH1, } 250 \\
\text { MSH2, } 71 \text { MSH6) }\end{array}$ & $\begin{array}{l}3410 \\
\text { individuals } \\
\text { No further } \\
\text { details } \\
\text { given }\end{array}$ \\
\hline $\begin{array}{l}\text { Development } \\
\text { method }\end{array}$ & $\begin{array}{l}\text { Multivariable } \\
\text { logistic } \\
\text { regression }\end{array}$ & $\begin{array}{l}\text { Multivariable logistic } \\
\text { regression }\end{array}$ & Multivariable logistic regression & $\begin{array}{l}\text { Application of the } \\
\text { Mendelian laws }\end{array}$ & $\begin{array}{l}\text { Application of the } \\
\text { Bayes' rule and } \\
\text { Mendelian laws }\end{array}$ & $\begin{array}{l}\text { Multivariable } \\
\text { logistic regression }\end{array}$ & Multivariable logistic regression & $\begin{array}{l}\text { Multivariable logistic } \\
\text { regression }\end{array}$ & Not stated \\
\hline Input & $\begin{array}{l}\text { Fulfilment of } \\
\text { AC-II (yes/ } \\
\text { no) } \\
\text { Mean age at } \\
\text { diagnosis of } \\
\text { CRC of } \\
\text { affected } \\
\text { relatives } \\
\text { EC in family } \\
\text { members } \\
\text { (yes/no) }\end{array}$ & $\begin{array}{l}\text { Fulfilment of AC-II } \\
\text { (yes/no) } \\
\text { Number of relatives } \\
\text { with CRC } \\
\text { Number of relatives } \\
\text { with }>1 \text { CRC and/or } \\
\text { EC } \\
\text { Number of relatives } \\
\text { with EC } \\
\text { Mean age at } \\
\text { diagnosis of CRC and } \\
\text { EC of affected } \\
\text { relatives } \\
\text { Number of relatives } \\
\text { with }>5 \text { adenomas }\end{array}$ & $\begin{array}{l}\text { Number of relatives with } \\
\text { CRC } \\
\text { Number of relatives with >1 } \\
\text { CRC and/or EC } \\
\text { Number of relatives with EC } \\
\text { Mean age at diagnosis of } \\
\text { CRC and EC of affected } \\
\text { relatives } \\
\text { Number of relatives with >5 } \\
\text { adenomas }\end{array}$ & $\begin{array}{l}\text { For the counselee } \\
\text { and each relative: } \\
\text { Exact relation } \\
\text { to the } \\
\text { counselee } \\
\text { CRC (yes, no) } \\
\text { Age at } \\
\text { diagnosis of } \\
\text { CRC if affected } \\
(<45,45-60, \\
>60 \text { years) } \\
\text { EC (yes, no) } \\
\text { Result of MSI } \\
\text { testing } \\
\text { (instability } \\
\text { present or not } \\
\text { present) if } \\
\text { tumour } \\
\text { available }\end{array}$ & $\begin{array}{l}\text { For the counselee } \\
\text { and each FDR or } \\
\text { SDR: } \\
\text { - Exact relation to } \\
\text { the counselee } \\
\text { Type of cancer } \\
\text { Age at diagnosis } \\
\text { (years) if affected } \\
\text { Current age or } \\
\text { age at death or } \\
\text { last follow-up } \\
\text { (years) if } \\
\text { unaffected } \\
\text { Result of MSI } \\
\text { (instability } \\
\text { present or not) or } \\
\text { IHC (loss of } \\
\text { expression or } \\
\text { present) if tumour } \\
\text { available } \\
\text { Result of previous } \\
\text { germline testing } \\
\text { (positive or } \\
\text { negative) }\end{array}$ & $\begin{array}{l}\text { For the counselee: } \\
\text { Age at } \\
\text { diagnosis } \\
\text { (years) } \\
\text { Sex } \\
\text { Tumour location } \\
\text { (proximal, } \\
\text { distal) } \\
\text { - Synchronous } \\
\text { and/or } \\
\text { metachronous } \\
\text { (yes, no) } \\
\text { For FDR: } \\
\text { CRC (yes, no) } \\
\text { Youngest age at } \\
\text { diagnosis of } \\
\text { CRC if affected } \\
\text { (<50 or } \\
\geq 50 \text { years) } \\
\text { - EC (yes, no) }\end{array}$ & $\begin{array}{l}\text { For the counselee: } \\
\text { CRC (none, one, } \geq 2 \text { ); age at } \\
\text { diagnosis if one, youngest age at } \\
\text { diagnosis if } \geq 2 \\
\text { Colonic adenoma (yes, no); } \\
\text { youngest age at diagnosis if } \\
\text { affected } \\
\text { EC (yes, no); youngest age at } \\
\text { diagnosis } \\
\text { HNPCC-associated cancer }{ }^{*} \text { (yes, } \\
\text { no) For FDR and SDR (only from } \\
\text { affected side of family): } \\
\text { Number of relatives with CRC } \\
\text { (none, one, } \geq 2 \text { ); Age at } \\
\text { diagnosis if one, youngest age at } \\
\text { diagnosis if } \geq 2 \\
\text { Number of relatives with EC } \\
\text { (none, one, } \geq 2 \text { ); age at } \\
\text { diagnosis if one, youngest age at } \\
\text { diagnosis if } \geq 2 \\
\text { Any relatives with another } \\
\text { HNPCC-associated cancer* (yes, } \\
\text { no) }\end{array}$ & $\begin{array}{l}\text { For the counselee: } \\
\text { Sex } \\
\text { CRC (none, one, } \geq 2 \text { ); } \\
\text { age at diagnosis if one, } \\
\text { youngest age at } \\
\text { diagnosis if } \geq 2 \\
\text { EC (yes, no); youngest } \\
\text { age at diagnosis } \\
\text { HNPCC-associated } \\
\text { cancer* (yes, no) } \\
\text { For FDR and SDR (only } \\
\text { from affected side of } \\
\text { family): } \\
\text { Number of relatives } \\
\text { with CRC (none, one, } \\
\geq 2 \text { ); age at diagnosis if } \\
\text { one, youngest age at } \\
\text { diagnosis if } \geq 2 \\
\text { Number of relatives } \\
\text { with EC (none, one, } \\
\geq 2 \text { ); age at diagnosis if } \\
\text { one, youngest age at } \\
\text { diagnosis if } \geq 2 \\
\text { Any relatives with } \\
\text { another } \\
\text { HNPCC-associated } \\
\text { cancer* (yes, no) }\end{array}$ & $\begin{array}{l}\text { Not } \\
\text { required }\end{array}$ \\
\hline
\end{tabular}




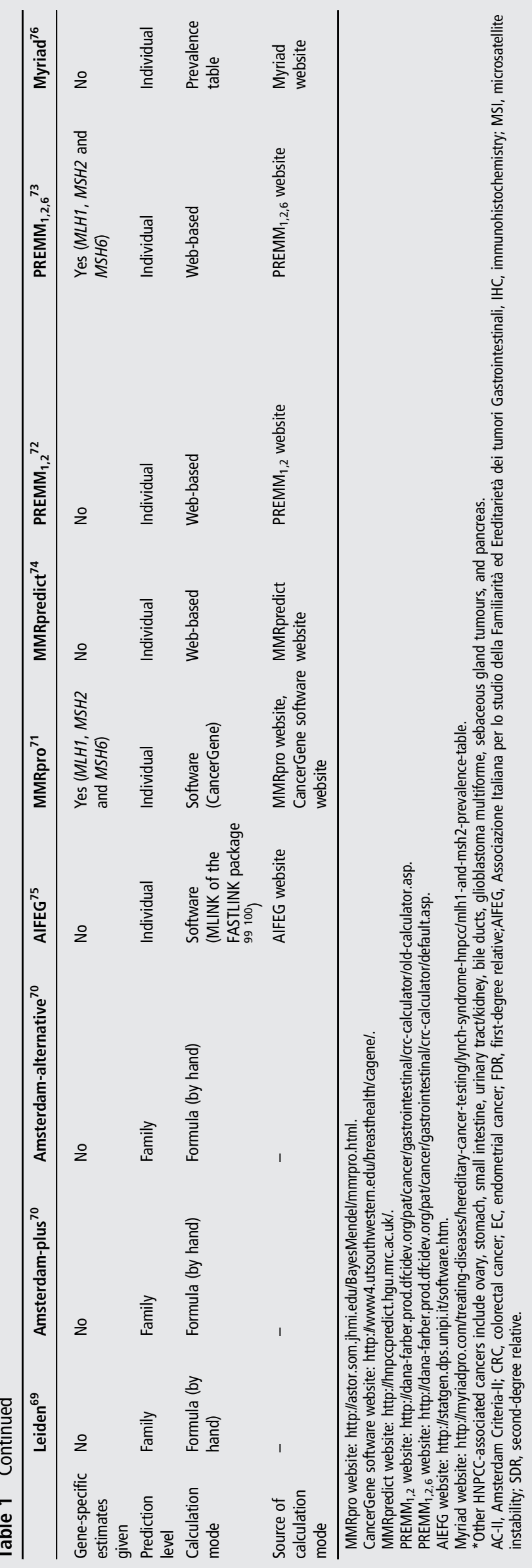

Table 2 Summary of meta-analyses of the area-under curves from studies that evaluated risk prediction models for mismatch repair (MMR) gene mutations

\begin{tabular}{|c|c|c|c|c|}
\hline Model & Sample & $I^{2}(\%)$ & $\begin{array}{l}\text { Heterogeneity } \\
\text { p value }\end{array}$ & $\begin{array}{l}\text { Pooled AUC } \\
(95 \% \mathrm{CI})\end{array}$ \\
\hline \multicolumn{5}{|l|}{ PREMM } \\
\hline & Clinic-based & 72.3 & $<0.001$ & 0.82 (0.79 to 0.86$)$ \\
\hline & Population-based & 73.8 & 0.004 & 0.88 (0.84 to 0.92 ) \\
\hline & Combined & 82.4 & $<0.001$ & 0.84 (0.81 to 0.88 ) \\
\hline \multicolumn{5}{|c|}{ MMRpro } \\
\hline & Clinic-based & 69.0 & 0.004 & 0.79 (0.73 to 0.84$)$ \\
\hline & Population-based & 80.5 & 0.02 & 0.88 (0.70 to 1.05$)$ \\
\hline & Combined & 92.5 & $<0.001$ & 0.80 (0.72 to 0.88$)$ \\
\hline \multicolumn{5}{|c|}{ MMRpredict } \\
\hline & Clinic-based & 77.4 & $<0.001$ & 0.77 ( 0.70 to 0.84$)$ \\
\hline & Population-based & 74.8 & 0.008 & 0.89 (0.81 to 0.98 ) \\
\hline & Combined & 91.5 & $<0.001$ & 0.81 (0.73 to 0.88 ) \\
\hline \multicolumn{5}{|l|}{ Leiden } \\
\hline & Clinic-based & 47.5 & 0.11 & 0.82 (0.78 to 0.87 ) \\
\hline & Population-based ${ }^{*}$ & - & - & 0.93 (0.91 to 0.95 ) \\
\hline & Combined & 88.4 & $<0.001$ & 0.85 (0.78 to 0.91$)$ \\
\hline
\end{tabular}

MMRpredict and 0.82 (95\% CI 0.75 to 0.88) for PREMM (see online supplementary table S2). Given the high degree of overlap in the CIs, we cannot state that one model has a higher discrimination than any of the others.

\section{SUMMARY}

We have reviewed all major criteria and prediction models for MMR gene mutation status, which are currently available. This review is increasingly important, as consideration for who to screen and test for MMR gene mutations is now broader than it was in the past.

Overall, the existing prediction models are sensitive and specific with an AUC of approximately $90 \%$. By contrast to the clinical or clinicopathological criteria that are dichotomous (yes/ no for screening followed by germline testing), the prediction models provide a probability of having a MMR gene mutation for a family or an individual and, therefore, a cut-off point of probability needs to be set for when to test for the genetic mutation. Several levels have been suggested; for example, anyone with a $5 \%$ or greater probability of being carriers. ${ }^{94}$ Dinh et $a l^{95}$ observed that direct germline testing for MMR gene mutations in people aged $25-35$ years with a $5 \%$ or greater risk of being carriers predicted by PREMM $\mathrm{P}_{1,2,6}$ ' $\ldots$ could improve health outcomes in a cost-effective manner relative to current practice' (initial screening by IHC and/or MSI followed by germline testing for colorectal cancer-affected people with a strong family history). This recommendation is in line with the National Comprehensive Cancer Network, ${ }^{96}$ which supports direct germline testing for MMR gene mutations for individuals with a $5 \%$ or greater risk of being carriers when a tumour sample is not readily available. For families in which there is no colorectal cancer tumour available for initial screening, this recommendation could result in numerous potential negative full gene screens and potentially increase costs compared within families where a colorectal tumour could be used for initial screening followed by germline testing. 
Kastrinos et $a l^{92} 9798$ proposed an algorithm for germline testing: IHC followed by MSI (and also BRAF testing for loss of MLH1 protein expression) in people diagnosed with colorectal cancer who have a $5 \%$ or greater probability of mutation according to PREMM $_{1,2,6}$. For a fast implementation of IHC analyses for MMR-deficiencies in combination with molecular analysis of BRAF mutations and/or MLH1 promoter methylation, new technology will be required as part of the diagnostic setting for all Lynch syndrome-associated cancers. Further, implementation of targeted sequencing of genes by nextgeneration sequencing will probably challenge the diagnostics of Lynch syndrome as it is expected to deliver lower costs and faster time of analysis.

Currently, all these models are free and publicly available. The cut-off level needs to be set by individual clinics depending on their resources and the proportion of mutation carriers they want to identify. Future models may need to: (1) provide prediction of PMS2 mutations, (2) take into account a wider range of Lynch syndrome-associated cancers when assessing family history and (3) be applicable to all people irrespective of any cancer diagnosis.

Contributors AKW carried out study concept and design, literature review, collection and assembly of data, analysis and interpretation of data, drafting and final approval of manuscript. RJM, JGD and MAJ carried out study concept and design, interpretation of data, drafting and final approval of manuscript.

Funding AKW is supported by the Picchi Brothers Foundation Cancer Council Victoria Cancer Research Scholarship, Australia. MAJ is a National Health and Medical Research Council Senior Research Fellow, Australia.

\section{Competing interests None.}

Provenance and peer review Not commissioned; externally peer reviewed.

\section{REFERENCES}

1 Jass JR. Hereditary Non-Polyposis Colorectal Cancer: the rise and fall of a confusing term. World I Gastroenterol 2006;12:4943-50.

2 Papadopoulos N, Nicolaides NC, Wei YF, Ruben SM, Carter KC, Rosen CA, Haseltine WA, Fleischmann RD, Fraser CM, Adams MD, Venter JC, Hamilton SR, Petersen GM, Watson P, Lynch HT, Peltomaki P, Mecklin JP, de La Chapelle A, Kinzler KW, Vogelstein B. Mutation of a mutL homolog in hereditary colon cancer. Science 1994:263:1625-9.

3 Bronner CE, Baker SM, Morrison PT, Warren G, Smith LG, Lescoe MK, Kane M, Earabino C, Lipford J, Lindblom A, Tannergard P, Bollag RJ, Godwin AR, Ward DC, Nordenskjld M, Fishel R, Kolodner R, Liskay RM. Mutation in the DNA mismatch repair gene homologue hMLH 1 is associated with hereditary non-polyposis colon cancer. Nature 1994;368:258-61.

4 Leach FS, Nicolaides NC, Papadopoulos N, Liu B, Jen J, Parsons R, Peltomäki P, Sistonen P, Aaltonen LA, Nyström-Lahti M, Guan XY, Zhang J, Meltzer PS, Yu J-W, Kao F-T, Chen DJ, Cerosaletti KM, Fournier REK, Todd S, Lewis T, Leach RJ, Naylor SL, Weissenbach J, Mecklin J-P, Järvinen H, Petersen GM, Hamilton SR, Green J, Jass J, Watson P, Lynch HT, Trent JM, de la Chapelle A, Kinzler KW, Vogelstein B. Mutations of a mutS homolog in hereditary nonpolyposis colorectal cancer. Cell 1993;75:1215-25.

5 Miyaki M, Konishi M, Tanaka K, Kikuchi-Yanoshita R, Muraoka M, Yasuno M, Igari T, Koike M, Chiba M, Mori T. Germline mutation of MSH6 as the cause of hereditary nonpolyposis colorectal cancer. Nat Genet 1997;17:271-2.

6 Akiyama Y, Sato H, Yamada T, Nagasaki H, Tsuchiya A, Abe R, Yuasa Y. Germ-line mutation of the hMSH6/GTBP gene in an atypical hereditary nonpolyposis colorectal cancer kindred. Cancer Res 1997;57:3920-3.

7 Nicolaides NC, Papadopoulos N, Liu B, Weit Y-F, Carter KC, Ruben SM, Rosen CA, Haseltine WA, Fleischmann RD, Fraser CM, Adams MD, Venter JC, Dunlop MG, Hamilton SR, Petersen GM, de la Chapelle A, Vogelstein B, Kinzler KW. Mutations of two PMS homologues in hereditary nonpolyposis colon cancer. Nature 1994;371:75-80.

8 Hendriks YM, Jagmohan-Changur $S$, van der Klift HM, Morreau H, van Puijenbroek M, Tops C, van Os T, Wagner A, Ausems MG, Gomez E, Breuning MH, Brocker-Vriends AH, Vasen HF, Wijnen JT. Heterozygous mutations in PMS2 cause hereditary nonpolyposis colorectal carcinoma (Lynch syndrome). Gastroenterology 2006;130:312-22.

9 Ligtenberg MJ, Kuiper RP, Chan TL, Goossens M, Hebeda KM, Voorendt M, Lee TY, Bodmer D, Hoenselaar E, Hendriks-Cornelissen SJ, Tsui WY, Kong CK, Brunner HG, van Kessel AG, Yuen ST, van Krieken JH, Leung SY, Hoogerbrugge N.
Heritable somatic methylation and inactivation of $\mathrm{MSH} 2$ in families with Lynch syndrome due to deletion of the $3^{\prime}$ exons of TACSTD1. Nat Genet 2009:41:112-17.

10 Kovacs ME, Papp J, Szentirmay Z, Otto S, Olah E. Deletions removing the last exon of TACSTD1 constitute a distinct class of mutations predisposing to Lynch syndrome. Hum Mutat 2009;30:197-203.

11 Aaltonen LA, Sankila R, Mecklin JP, Jarvinen H, Pukkala E, Peltomaki P, de la Chapelle A. A novel approach to estimate the proportion of hereditary nonpolyposis colorectal cancer of total colorectal cancer burden. Cancer Detect Prev 1994;18:57-63.

12 Burt RW, DiSario JA, Cannon-Albright L. Genetics of colon cancer: impact of inheritance on colon cancer risk. Annu Rev Med 1995;46:371-9.

13 Hampel H, Frankel WL, Martin E, Arnold M, Khanduja K, Kuebler P, Clendenning M, Sotamaa K, Prior T, Westman JA, Panescu J, Fix D, Lockman J, LaJeunesse J, Comeras I, de la Chapelle A. Feasibility of Screening for Lynch Syndrome Among Patients With Colorectal Cancer. J Clin Oncol 2008;26:5783-8.

14 Hampel H, Frankel WL, Martin E, Arnold M, Khanduja K, Kuebler P, Nakagawa H, Sotamaa K, Prior TW, Westman J, Panescu J, Fix D, Lockman J, Comeras I, de la Chapelle A. Screening for the Lynch Syndrome (Hereditary Nonpolyposis Colorectal Cancer). N Engl J Med 2005;352:1851-60.

15 de la Chapelle A. The incidence of Lynch syndrome. Fam Cancer 2005;4:233-7.

16 Salovaara R, Loukola A, Kristo P, Kaariainen H, Ahtola H, Eskelinen M, Harkonen N, Julkunen R, Kangas E, Ojala S, Tulikoura J, Valkamo E, Jarvinen $H_{\text {, }}$ Mecklin J-P, Aaltonen LA, de la Chapelle A. Population-based molecular detection of hereditary nonpolyposis colorectal cancer. J Clin Oncol 2000;18:2193-200.

17 Hopper JL. Application of genetics to the prevention of colorectal cancer. Recent Results Cancer Res 2005;166:17-33.

18 Aaltonen L, Johns L, Jarvinen H, Mecklin J-P, Houlston R. Explaining the familial colorectal cancer risk associated with Mismatch Repair (MMR)-deficient and MMR-stable tumors. Clin Cancer Res 2007;13:356-61.

19 Hampel $\mathrm{H}$, de la Chapelle A. The search for unaffected individuals with lynch syndrome: do the ends justify the means? Cancer Prev Res 2011;4:1-5.

20 Dunlop MG, Farrington SM, Nicholl I, Aaltonen L, Petersen G, Porteous M, Carothers A. Population carrier frequency of hMSH2 and hMLH1 mutations. $\mathrm{Br} J$ Cancer 2000;83:1643-5.

21 Terdiman JP. HNPCC: an uncommon but important diagnosis. Gastroenterology 2001;121:1005-8.

22 Boland CR, Shike M. Report from the Jerusalem workshop on Lynch syndrome-hereditary nonpolyposis colorectal cancer. Gastroenterology 2010;139:2197 e1-7.

23 Umar A, Boland CR, Terdiman JP, Syngal S, Chapelle Adl, Ruschoff J, Fishel R, Lindor NM, Burgart LJ, Hamelin R, Hamilton SR, Hiatt RA, Jass J, Lindblom A, Lynch HT, Peltomaki P, Ramsey SD, Rodriguez-Bigas MA, Vasen HFA, Hawk ET, Barrett JC, Freedman AN, Srivastava S. Revised Bethesda guidelines for hereditary nonpolyposis colorectal cancer (lynch syndrome) and microsatellite instability. J Natl Cancer Inst 2004;96:261-8.

24 Kastrinos F, Mukherjee B, Tayob N, Wang F, Sparr J, Raymond VM, Bandipalliam P, Stoffel EM, Gruber SB, Syngal S. Risk of pancreatic cancer in families with Lynch syndrome. JAMA 2009;302:1790-5.

25 Win AK, Young JP, Lindor NM, Tucker K, Ahnen D, Young GP, Buchanan D, Clendenning M, Giles G, Winship I, Macrae F, Goldblatt J, Southey M, Arnold J, Thibodeau SN, Gunawardena SR, Bapat B, Baron JA, Casey G, Le Marchand L, Newcomb P, Haile R, Hopper JL, Jenkins MA. Colorectal and other cancer risks for carriers and noncarriers from families with a DNA mismatch repair gene mutation: a prospective cohort study. J Clin Oncol 2012;30:958-64.

26 Raymond VM, Mukherjee B, Wang F, Huang SC, Stoffel EM, Kastrinos F, Syngal S, Cooney KA, Gruber SB. Elevated risk of prostate cancer among men with lynch syndrome. J Clin Oncol 2013;31:1713-18.

27 Win AK, Lindor NM, Young JP, Macrae FA, Young GP, Williamson E, Parry $S$, Goldblatt J, Lipton L, Winship I, Leggett B, Tucker K, Giles G, Buchanan D, Clendenning M, Rosty C, Arnold J, Levine AJ, Haile RW, Gallinger S, Le Marchand L, Newcomb PA, Hopper JL, Jenkins MA. Risks of primary extracolonic cancers following colorectal cancer in Lynch syndrome. J Natl Cancer Inst 2012;104:1363-72.

28 Win AK, Lindor NM, Winship I, Tucker KM, Buchanan DD, Young JP, Rosty C, Leggett B, Giles GG, Goldblatt J, Macrae FA, Parry S, Kalady MF, Baron JA, Ahnen DJ, Marchand LL, Gallinger S, Haile RW, Newcomb PA, Hopper JL, Jenkins MA. Risks of colorectal and other cancers after endometrial cancer for women with lynch syndrome. J Nat/ Cancer Inst 2013;105:274-9.

29 Win AK, Lindor N, Jenkins M. Risk of breast cancer in Lynch syndrome: a systematic review. Breast Cancer Res 2013;15:R27.

30 Dowty JG, Win AK, Buchanan DD, Lindor NM, Macrae FA, Clendenning M, Antill YC, Thibodeau SN, Casey G, Gallinger S, Marchand LL, Newcomb PA, Haile RW, Young GP, James PA, Giles GG, Gunawardena SR, Leggett BA, Gattas M, Boussioutas A, Ahnen DJ, Baron JA, Parry S, Goldblatt J, Young JP, Hopper JL, Jenkins MA. Cancer risks for MLH1 and MSH2 mutation carriers. Hum Mutat 2013;34:490-7. 
31 Jarvinen $\mathrm{HJ}$, Aarnio M, Mustonen $\mathrm{H}$, Aktan-Collan $\mathrm{K}$, Aaltonen LA, Peltomaki $\mathrm{P}$, De La Chapelle A, Mecklin JP. Controlled 15-year trial on screening for colorectal cancer in families with hereditary nonpolyposis colorectal cancer. Gastroenterology 2000;118:829-34

32 de Jong AE, Hendriks YMC, Kleibeuker JH, de Boer SY, Cats A, Griffioen G, Nagengast FM, Nelis FG, Rookus MA, Vasen HFA. Decrease in mortality in lynch syndrome families because of surveillance. Gastroenterology 2006;130:665-71.

33 Schmeler KM, Lynch HT, Chen LM, Munsell MF, Soliman PT, Clark MB, Daniels MS, White KG, Boyd-Rogers SG, Conrad PG, Yang KY, Rubin MM, Sun CC, Slomovitz BM, Gershenson DM, Lu KH. Prophylactic surgery to reduce the risk of gynecologic cancers in the Lynch syndrome. $N$ Engl I Med 2006;354:261-9.

34 Burn J, Gerdes AM, Macrae F, Mecklin JP, Moeslein G, Olschwang S, Eccles D, Evans DG, Maher ER, Bertario L, Bisgaard ML, Dunlop MG, Ho JW, Hodgson SV, Lindblom A, Lubinski J, Morrison PJ, Murday V, Ramesar R, Side L, Scott RJ, Thomas HJ, Vasen HF, Barker G, Crawford G, Elliott F, Movahedi M,

Pylvanainen K, Wijnen JT, Fodde R, Lynch HT, Mathers JC, Bishop DT. Long-term effect of aspirin on cancer risk in carriers of hereditary colorectal cancer: an analysis from the CAPP2 randomised controlled trial. Lancet 2011;9809:2081-7.

35 Vasen HF, Mecklin JP, Khan PM, Lynch HT. The International Collaborative Group on Hereditary Non-Polyposis Colorectal Cancer (ICG-HNPCC). Dis Colon Rectum 1991;34:424-5.

36 Percesepe A, Anti M, Roncucci L, Armelao F, Marra G, Pahor M, Coco C Gasbarrini G, Ponz de Leon $M$. The effect of family size on estimates of the frequency of hereditary non-polyposis colorectal cancer. $\mathrm{Br}$ I Cancer 1995;72:1320-3

37 Bisgaard ML, Jager AC, Myrhoj T, Bernstein I, Nielsen FC. Hereditary non-polyposis colorectal cancer (HNPCC): phenotype-genotype correlation between patients with and without identified mutation. Hum Mutat 2002;20:20-7.

38 Syngal S, Fox EA, Eng C, Kolodner RD, Garber JE. Sensitivity and specificity of clinical criteria for hereditary non-polyposis colorectal cancer associated mutations in MSH2 and MLH1. J Med Genet 2000;37:641-5.

39 Wijnen J, Khan PM, Vasen H, van der Klift H, Mulder A, van Leeuwen-Cornelisse I, Bakker B, Losekoot M, Moller P, Fodde R. Hereditary nonpolyposis colorectal cancer families not complying with the Amsterdam criteria show extremely low frequency of mismatch-repair-gene mutations. Am J Hum Genet 1997;61:329-35.

40 Moslein G, Tester DJ, Lindor NM, Honchel R, Cunningham JM, French AJ, Halling KC, Schwab M, Goretzki P, Thibodeau SN. Microsatellite instability and mutation analysis of hMSH2 and hMLH1 in patients with sporadic, familial and hereditary colorectal cancer. Hum Mol Genet 1996;5:1245-52.

41 Wang Q, Lasset C, Desseigne F, Saurin JC, Maugard C, Navarro C, Ruano E, Descos L, Trillet-Lenoir V, Bosset JF, Puisieux A. Prevalence of germline mutations of hMLH1, hMSH2, hPMS1, hPMS2, and hMSH6 genes in 75 French kindreds with nonpolyposis colorectal cancer. Hum Genet 1999;105:79-85.

42 Kievit W, de Bruin JH, Adang EM, Ligtenberg MJ, Nagengast FM, van Krieken JH, Hoogerbrugge N. Current clinical selection strategies for identification of hereditary non-polyposis colorectal cancer families are inadequate: a meta-analysis. Clin Genet 2004:65:308-16.

43 Liu B, Parsons R, Papadopoulos N, Nicolaides NC, Lynch HT, Watson P, Jass JR, Dunlop M, Wyllie A, Peltomaki P, de la Chapelle A, Hamilton SR, Vogelstein B, Kinzler KW. Analysis of mismatch repair genes in hereditary non-polyposis colorectal cancer patients. Nat Med 1996;2:169-74.

44 Vasen HFA, Watson P, Mecklin JP, Lynch HT. New clinical criteria for hereditary nonpolyposis colorectal cancer (HNPCC, Lynch syndrome) proposed by the International Collaborative Group on HNPCC. Gastroenterology 1999;116:1453-6.

45 Katballe N, Christensen M, Wikman FP, Orntoft TF, Laurberg S. Frequency of hereditary non-polyposis colorectal cancer in Danish colorectal cancer patients. Gut 2002;50:43-51

46 Park JG, Vasen HF, Park YJ, Park KJ, Peltomaki P, de Leon MP, Rodriguez-Bigas MA, Lubinski J, Beck NE, Bisgaard ML, Miyaki M, Wijnen JT, Baba S, Lindblom A, Madlensky L, Lynch HT. Suspected HNPCC and Amsterdam criteria II: evaluation of mutation detection rate, an international collaborative study. Int I Colorectal Dis 2002;17:109-14.

47 Ponz de Leon M, Sassatelli R, Benatti P, Roncucci L. Identification of hereditary nonpolyposis colorectal cancer in the general population. The 6-year experience of a population-based registry. Cancer 1993;71:3493-501.

48 Benatti P, Sassatelli R, Roncucci L, Pedroni M, Fante R, Di Gregorio C, Losi L, Gelmini R, Ponz de Leon M. Tumour spectrum in hereditary non-polyposis colorectal cancer (HNPCC) and in families with "suspected HNPCC". A population-based study in northern Italy. Colorectal Cancer Study Group. Int $J$ Cancer 1993:54:371-7.

49 Madlensky L, Berk TC, Bapat BV, McLeod RS, Couture J, Baron D, Hiruki T, Redston $\mathrm{M}$, Cohen Z, Gallinger S. A preventive registry for hereditary nonpolyposis colorectal cancer. Can J Oncol 1995;5:355-60.

50 Fujita S, Moriya Y, Sugihara K, Akasu T, Ushio K. Prognosis of hereditary nonpolyposis colorectal cancer (HNPCC) and the role of Japanese criteria for HNPCC. Jpn J Clin Oncol 1996;26:351-5.
51 Han HJ, Yuan Y, Ku JL, Oh JH, Won YJ, Kang KJ, Kim KY, Kim S, Kim CY, Kim JP, Oh NG, Lee KH, Choe KJ, Nakamura Y, Park JG. Germline mutations of hMLH1 and hMSH2 genes in Korean hereditary nonpolyposis colorectal cancer. J Natl Cancer Inst 1996;88:1317-9.

52 Shu Z, Yanqin $\mathrm{H}$, Ying Y. Hereditary colorectal cancer in china. Hered Cancer Clin Pract 2005;3:155-64.

53 Rodriguez-Bigas M, Boland C, Hamilton S, Henson D, Srivastava S, Jass J, Khan P, Lynch H, Smyrk T, Perucho M. A National Cancer Institute workshop on hereditary nonpolyposis colorectal cancer syndrome: meeting highlights and Bethesda guidelines. J Natl Cancer Inst 1997;89:1758-62.

54 Southey MC, Jenkins MA, Mead L, Whitty J, Trivett M, Tesoriero AA, Smith LD, Jennings K, Grubb G, Royce SG, Walsh MD, Barker MA, Young JP, Jass JR, St John DJB, Macrae FA, Giles GG, Hopper JL. Use of molecular tumor characteristics to prioritize mismatch repair gene testing in early-onset colorectal cancer. J Clin Oncol 2005;23:6524-32.

55 Jenkins MA, Dowty JG, Hopper JL, Southey MC. Molecular screening of all colorectal tumors diagnosed before age 50 years followed by genetic testing efficiently identifies Lynch syndrome cases. Int I Cancer 2009;124:x-xi.

56 Schofield L, Watson N, Grieu F, Li WQ, Zeps N, Harvey J, Stewart C, Abdo M, Goldblatt J, lacopetta B. Population-based detection of Lynch syndrome in young colorectal cancer patients using microsatellite instability as the initial test. Int J Cancer 2009;124:1097-102.

57 Schofield L, Grieu F, Goldblatt J, Amanuel B, lacopetta B. A state-wide population-based program for detection of lynch syndrome based upon immunohistochemical and molecular testing of colorectal tumours. Fam Cancer 2012:11:1-6.

58 Pinol V, Castells A, Andreu M, Castellvi-Bel S, Alenda C, Llor X, Xicola RM, Rodriguez-Moranta F, Paya A, Jover R, Bessa X. Accuracy of revised Bethesda guidelines, microsatellite instability, and immunohistochemistry for the identification of patients with hereditary nonpolyposis colorectal cancer. JAMA 2005;293:1986-94.

59 Hampel H, Frankel W, Panescu J, Lockman J, Sotamaa K, Fix D, Comeras I, La Jeunesse J, Nakagawa H, Westman JA, Prior TW, Clendenning M, Penzone $P$, Lombardi J, Dunn P, Cohn DE, Copeland L, Eaton L, Fowler J, Lewandowski G, Vaccarello L, Bell J, Reid G, de la Chapelle A. Screening for lynch syndrome (hereditary nonpolyposis colorectal cancer) among endometrial cancer patients. Cancer Res 2006;66:7810-17.

60 Moreira L, Balaguer F, Lindor N, de la Chapelle A, Hampel H, Aaltonen LA, Hopper JL, Le Marchand L, Gallinger S, Newcomb PA, Haile R, Thibodeau SN, Gunawardena S, Jenkins MA, Buchanan DD, Potter JD, Baron JA, Ahnen DJ, Moreno V, Andreu M, Ponz de Leon M, Rustgi AK, Castells A. Identification of Lynch syndrome among patients with colorectal cancer. JAMA 2012;308:1555-65.

61 Evaluation of Genomic Applications in Practice and Prevention (EGAPP) Working Group. Recommendations from the EGAPP Working Group. Genetic testing strategies in newly diagnosed individuals with colorectal cancer aimed at reducing morbidity and mortality from Lynch syndrome in relatives. Genet Med 2009;11:35-41.

62 Deng G, Bell I, Crawley S, Gum J, Terdiman JP, Allen BA, Truta B, Sleisenger MH, Kim YS. BRAF mutation is frequently present in sporadic colorectal cancer with methylated hMLH1, but not in hereditary nonpolyposis colorectal cancer. Clin Cancer Res 2004;10(1 Pt 1):191-5.

63 Domingo E, Laiho $P$, Ollikainen M, Pinto M, Wang L, French AJ, Westra J, Frebourg T, Espin E, Armengol M, Hamelin R, Yamamoto H, Hofstra RM, Seruca R, Lindblom A, Peltomaki P, Thibodeau SN, Aaltonen LA, Schwartz S Jr. BRAF screening as a low-cost effective strategy for simplifying HNPCC genetic testing. J Med Genet 2004;41:664-8.

64 Ladabaum U, Wang G, Terdiman J, Blanco A, Kuppermann M, Boland CR, Ford J, Elkin E, Phillips KA. Strategies to identify the Lynch syndrome among patients with colorectal cancer: a cost-effectiveness analysis. Ann Intern Med 2011;155:69-79.

65 Mvundura M, Grosse SD, Hampel H, Palomaki GE. The cost-effectiveness of genetic testing strategies for Lynch syndrome among newly diagnosed patients with colorectal cancer. Genet Med 2010;12:93-104.

66 Baba S. Hereditary nonpolyposis colorectal cancer: an update. Dis Colon Rectum 1997:40:586-95.

67 Ramsey S, Clarke L, Etzioni R, Higashi M, Berry K, Urban N. Cost-effectiveness of microsatellite instability screening as a method for detecting hereditary nonpolyposis colorectal cancer. Ann Intern Med 2001;135(8 Part 1):577.

68 Grover S, Stoffel E, Bussone L, Tschoegl E, Syngal S. Physician assessment of family cancer history and referral for genetic evaluation in colorectal cancer patients. Clin Gastroenterol Hepatol 2004;2:813-19.

69 Wijnen JT, Vasen HFA, Khan PM, Zwinderman AH, van der Klift $H$, Mulder $A$, Tops C, Møller P, Fodde R, Menko F, Taal B, Nagengast F, Brunner $H$, Kleibeuker J, Sijmons R, Griffioen $G$, Bröcker-Vriends $A$, Bakker $E$, van Leeuwen-Cornelisse I, Meijers-Heijboer A, Lindhout D, Breuning M, Post J, Schaap C, Apold J, Heimdal K, Bertario L, Bisgaard ML, Goetz P. Clinical findings with implications for genetic testing in families with clustering of colorectal cancer. N Engl J Med 1998;339:511-18. 
70 Lipton LR, Johnson V, Cummings C, Fisher S, Risby P, Eftekhar Sadat AT, Cranston T, Izatt L, Sasieni P, Hodgson SV, Thomas HJW, Tomlinson IPM. Refining the Amsterdam Criteria and Bethesda Guidelines: testing algorithms for the prediction of mismatch repair mutation status in the familial cancer clinic. J Clin Oncol 2004;22:4934-43.

71 Chen S, Wang W, Lee S, Nafa K, Lee J, Romans K, Watson P, Gruber SB, Euhus D, Kinzler KW. Prediction of germline mutations and cancer risk in the Lynch syndrome. JAMA 2006;296:1479-87.

72 Balmaña J, Stockwell DH, Steyerberg EW, Stoffel EM, Deffenbaugh AM, Reid JE, Ward B, Scholl T, Hendrickson B, Tazelaar J, Burbidge LA, Syngal S. Prediction of MLH1 and MSH2 mutations in lynch syndrome. JAMA 2006;296:1469-78.

73 Kastrinos F, Steyerberg EW, Mercado R, Balmaña J, Holter S, Gallinger S, Siegmund KD, Church JM, Jenkins MA, Lindor NM, Thibodeau SN, Burbidge LA, Wenstrup RJ, Syngal S. The PREMM 1,2,6 model predicts risk of MLH1, MSH2, and MSH6 germline mutations based on cancer history. Gastroenterology 2011;140:73-81.

74 Barnetson RA, Tenesa A, Farrington SM, Nicholl ID, Cetnarskyj R, Porteous ME, Campbell H, Dunlop MG. Identification and survival of carriers of mutations in DNA mismatch-repair genes in colon cancer. N Engl J Med 2006;354:2751-63.

75 Marroni F, Pastrello C, Benatti P, Torrini M, Barana D, Cordisco E, Viel A, Mareni C, Oliani C, Genuardi M, Bailey-Wilson J, Ponz de Leon M, Presciuttini S. A genetic model for determining MSH2 and MLH1 carrier probabilities based on family history and tumor microsatellite instability. Clin Genet 2006;69:254-62.

76 Myriad Genetic Laboratories. MLH1 and MSH2 Prevalence Table. 2007.

77 Palomaki GE, McClain MR, Melillo S, Hampel HL, Thibodeau SN. EGAPP supplementary evidence review: DNA testing strategies aimed at reducing morbidity and mortality from Lynch syndrome. Genet Med 2009;11:42-65.

78 Senter L, Clendenning M, Sotamaa K, Hampel H, Green J, Potter JD, Lindblom A, Lagerstedt K, Thibodeau SN, Lindor NM, Young J, Winship I, Dowty JG, White DM, Hopper JL, Baglietto L, Jenkins MA, de la Chapelle A. The clinical phenotype of lynch syndrome due to germ-line PMS2 mutations. Gastroenterology 2008:135:419-28.

79 Vickers AJ. Prediction models: revolutionary in principle, but do they do more good than harm? J Clin Oncol 2011:29:2951-2

80 Steyerberg EW, Vickers AJ, Cook NR, Gerds T, Gonen M, Obuchowski N, Pencina MJ, Kattan MW. Assessing the performance of prediction models: a framework for traditional and novel measures. Epidemiology 2010;21:128-38.

81 StataCorp. Stata Statistical Software: Release 11. College Station, TX: StataCorp LP, 2009.

82 Balaguer F, Balmaña J, Castellví-Bel S, Steyerberg EW, Andreu M, Llor X, Jover R, Syngal $S$, Castells A. Validation and extension of the PREMM1,2 model in a population-based cohort of colorectal cancer patients. Gastroenterology 2008;134:39-46.

83 Balmaña J, Balaguer F, Castellví-Bel S, Steyerberg EW, Andreu M, Llor X, Jover R, Castells A, Syngal S, Association ftGOGotSG. Comparison of predictive models, clinical criteria and molecular tumour screening for the identification of patients with Lynch syndrome in a population-based cohort of colorectal cancer patients. J Med Genet 2008;45:557-63.

84 Green R, Parfrey P, Woods M, Younghusband H. Prediction of Lynch syndrome in consecutive patients with colorectal cancer. J Natl Cancer Inst 2009;101:331.
85 Pouchet CJ, Wong N, Chong G, Sheehan MJ, Schneider G, Rosen-Sheidley B, Foulkes W, Tischkowitz M. A comparison of models used to predict MLH1, MSH2 and MSH6 mutation carriers. Ann Oncol 2009;20:681-8.

86 Ramsoekh D, van Leerdam ME, Wagner A, Kuipers EJ, Steyerberg EW. Mutation prediction models in Lynch syndrome: evaluation in a clinical genetic setting. J Med Genet 2009:46:745-51.

87 Backes FJ, Hampel H, Backes KA, Vaccarello L, Lewandowski G, Bell JA, Reid GC, Copeland LJ, Fowler JM, Cohn DE. Are prediction models for Lynch syndrome valid for probands with endometrial cancer? Fam Cancer 2009;8:483-7.

88 Monzon JG, Cremin C, Armstrong L, Nuk J, Young S, Horsman DE, Garbutt K, Bajdik CD, Gill $S$. Validation of predictive models for germline mutations in DNA mismatch repair genes in colorectal cancer. Int I Cancer 2010;126:930-9.

89 Khan O, Blanco A, Conrad P, Gulden C, Moss TZ, Olopade OI, Kupfer SS, Terdiman J. Performance of lynch syndrome predictive models in a multi-center US referral population. Am J Gastroenterol 2011;106:1822-7.

90 Monteiro Santos EM, Valentin MD, Carneiro F, de Oliveira LP, de Oliveira Ferreira F, Junior SA, Nakagawa WT, Gomy I, de Faria Ferraz VE, da Silva Junior WA, Carraro DM, Rossi BM. Predictive models for mutations in mismatch repair genes: implication for genetic counseling in developing countries. BMC Cancer 2012;12:64.

91 Tresallet $C$, Brouquet A, Julie C, Beauchet A, Vallot C, Menegaux F, Mitry E, Radvanyi F, Malafosse R, Rougier P, Nordlinger B, Laurent-Puig P, Boileau C, Emile JF, Muti C, Penna C, Hofmann-Radvanyi H. Evaluation of predictive models for the identification in daily practice of patients with lynch syndrome. Int I Cancer 2012;130:1367-77.

92 Kastrinos F, Steyerberg EW, Balmana J, Mercado R, Gallinger S, Haile R, Casey G, Hopper JL, Lemarchand L, Lindor NM, Newcomb PA, Thibodeau SN, Syngal S. Comparison of the clinical prediction model PREMM1,2,6 and molecular testing for the systematic identification of Lynch syndrome in colorectal cancer. Gut 2013:62:272-9.

93 Mercado RC, Hampel H, Kastrinos F, Steyerberg E, Balmana J, Stoffel E, Cohn DE, Backes FJ, Hopper IL, Jenkins MA, Lindor NM, Casey G, Haile R, Madhavan S, de la Chapelle A, Syngal S. Performance of PREMM $(1,2,6)$, MMRpredict, and MMRpro in detecting Lynch syndrome among endometrial cancer cases. Genet Med 2012;14:670-80.

94 Burt RW. Diagnosing Lynch syndrome: more light at the end of the tunnel. Cancer Prev Res (Phila) 2012:5:507-10.

95 Dinh TA, Rosner BI, Atwood JC, Boland CR, Syngal S, Vasen HF, Gruber SB, Burt RW. Health benefits and cost-effectiveness of primary genetic screening for Lynch syndrome in the general population. Cancer Prev Res (Phila) 2011;4:9-22.

96 National Comprehensive Cancer Network. NCCN Clinical Practice Guidelines in Oncology Version 1.2013. Colorectal Cancer Screening. Vol 2013. National Comprehensive Cancer Network, 2013.

97 Kastrinos F, Syngal S. Screening patients with colorectal cancer for lynch syndrome: what are we waiting for? I Clin Oncol 2012;30:1024-7.

98 Kastrinos F, Balmana J, Syngal S. Prediction models in Lynch syndrome. Fam Cancer 2013;12:217-28.

99 Cottingham RW Jr, Idury RM, Schaffer AA. Faster sequential genetic linkage computations. Am J Hum Genet 1993;53:252-63.

100 Schaffer AA, Gupta SK, Shriram K, Cottingham RW Jr. Avoiding recomputation in linkage analysis. Hum Hered 1994;44:225-37. 